\begin{tabular}{l} 
RCCS \\
\hline Annual Review
\end{tabular}

\section{RCCS Annual Review}

A selection from the Portuguese journal Revista Crítica de Ciências Sociais

6 | 2014

Issue no. 6

\title{
Environmental Colonialism, Criminalization and Resistance: Puerto Rican Mobilizations for Environmental Justice in the $21^{\text {st }}$ Century
}

José M. Atiles-Osoria

Translator. Karen Bennett

(2) OpenEdition

\section{Journals}

Electronic version

URL: http://journals.openedition.org/rccsar/524

DOI: $10.4000 /$ rccsar.524

ISSN: $1647-3175$

\section{Publisher}

Centro de Estudos Sociais da Universidade de Coimbra

Electronic reference

José M. Atiles-Osoria, «Environmental Colonialism, Criminalization and Resistance: Puerto Rican Mobilizations for Environmental Justice in the $21^{\text {st }}$ Century », RCCS Annual Review [Online], 6 | 2014, Online since 01 October 2014, connection on 30 April 2019. URL : http://journals.openedition.org/ rccsar/524; DOI : 10.4000/rccsar.524 
Centre for Social Studies, University of Coimbra, Portugal

\title{
Environmental Colonialism, Criminalization and Resistance: Puerto Rican Mobilizations for Environmental Justice in the $21^{\text {st }}$ Century* $^{*}$
}

\begin{abstract}
Struggles for environmental justice have become a fundamental part of Puerto Rican sociopolitical and anticolonial mobilizations since the mid-twentieth century. In this context, and paying particular attention to the criminalization processes used by the United States in the post 9/11 era, the article develops three lines of analysis: 1 ) a reflection on environmental colonialism in the context of Puerto Rico; 2 ) an analysis of the mechanisms of criminalization and repression developed by the governments of the US and Puerto Rico; 3) a review of the Puerto Rican socio-environmental conflicts between 1999 and 2012. The discussion of these points shows the close connection between Puerto Rican environmental and anti-colonial movements, as well as the mechanisms of repression and criminalization deployed against them.
\end{abstract}

Keywords: anti-colonialism; environmental colonialism; environmental justice; Puerto Rico; repression.

Since the 1990s, movements for environmental justice have gradually acquired a central role in the Puerto Rican sociopolitical imagination. This was the result of various processes to raise awareness and mobilize support for environmental protection that took place between the 1960s and 2012. Following the pioneering work of Concepción $(1988,1995)$, Baver (2006) and Valdés (2006) on the environmental struggles in Puerto Rico (PR), the concept of environmental justice is understood in this article as a category that groups together various claims and movements campaigning on issues such as environmental protection, the stoppage of contaminating practices and environmental decontamination, amongst other demands. These authors agree that, since the 1960s, a discourse on environmental justice has developed in PR, which may be read in terms of "rights" to a safe environment that is free from contamination and guarantees the wellbeing of communities. As will be shown in this article, this "right" has been vindicated using various strategies, though the most significant have involved legal movements and forms of social protest. The governments of the United States of America (US) and PR have generally been considered responsible for guaranteeing those rights. Thus, I consider that, within a colonial context such as that of PR, which experiences environmental colonialism, the concept of "environmental justice" operates as an explanatory category for a range of different struggles by socioenvironmental

\footnotetext{
*Article published in RCCS 100 (May 2013).
} 
movements. However, it should be pointed out that the concept is used somewhat theoretically, and that the socioenvironmental movements may employ other categories to describe their mobilizations. That is to say, most of the movements do not consider themselves to be movements for environmental justice, but rather define their struggles in terms of more concrete demands (e.g., environmental struggles, struggles against contamination, neighbourhood platforms to confront a particular problem, etc.). Thus, the concept of "environmental justice" will be used in this article as a theoretical category that aims to group together these diverse movements and struggles.

These mobilizations are, for their part, the result of broader and more complex processes of struggle for the decolonization of PR. This can be appreciated when it is recognised that, as Mattei and Nader (2008) point out, one of the primary manifestations of colonialism is the exploitation of the territory's natural and mineral resources, the extraction of its wealth and plundering of its material, cultural and environmental resources. Thus, the struggles for the decolonization of $P R$ and the movements for environmental justice cannot be understood independently, but have to be studied within a common historical framework.

In the wake of these mobilizations for environmental justice and for the decolonization of PR, the governments of the US and PR have deployed various mechanisms of repression and criminalization. Throughout the history of the environmental conflicts in PR, different repressive strategies have been used. Between the 1960s and 1990, repressive mechanisms were initially deployed to halt the advance of the anticolonial movements. Then, after 11 September 2001 (9/11) and the passing of the Patriot Act, the repressive measures and laws deployed have been specifically designed to deter and delegitimize Puerto Rican socioenvironmental movements.

This article focuses on socioenvironmental movements and criminalization processes used in PR between 1999 and 2012. It is divided into three sections: the first section will contextualize the colonial case of PR and discuss the concept of environmental colonialism and its sociopolitical and legal implications; the second section will show the various repression and criminalization mechanisms used by the governments of the US and PR against socioenvironmental movements; and finally, the third section will focus on some Puerto Rican socioenvironmental movements that appeared between 1999 and 2012. Thus, the article aims to describe, firstly, the relationship between the anticolonial and 
environmental struggles; and secondly, the development of the repression and criminalization of socioenvironmental protest in the colonial context of PR.

\section{Environmental colonialism in Puerto Rico}

PR is a Caribbean archipelago consisting of the Isla Grande, the island municipalities of Vieques and Culebra and a series of smaller islands. In environmental terms, PR enjoys great biodiversity, important nature and mineral reserves, reserves of drinking water and fertile soils. This fact, combined with its strategic geopolitical position in the Caribbean Sea, made it a key interest for colonisers, leading to over 500 years of colonial domination. For the last 114 years (1898 to 2012), it has been under US control, and this has had significant effects on the economic, environmental, sociopolitical and legal levels.

In economic terms, the country has been unable to develop its own economic agenda, as it has traditionally depended upon the interests of the colonizing agent. This dependency is manifest in the various economic models that have been imposed over the last hundred years, none of which have ever managed to achieve full yield. Examples are the radical economic transformations that occurred in the first decades of the $20^{\text {th }}$ century, when the country passed from what was predominantly subsistence farming to a sugar cane monoculture. Then, from 1940, the industrialization by invitation model, better known as Operation Bootstrap (Baver, 1993; Berman, 1996; Dietz, 1989), was implemented, establishing, amongst others, textile industries and oil refineries. The 1970s saw a new economic transition with the promotion of the pharmaceutical and electronic industries. Then, in the 1990s, the island's economic model became predominantly post-industrial, based on consumption and service industries, which led to the underdevelopment of agriculture and industry, and/or the abandonment of all the previous economic models, except the highly contaminating pharmaceutical and electronic industries.

In accordance with its economic (under)development, the US initiated a process of militarization of PR from 1940. This process, which extended throughout the Caribbean (García \& Vega, 2002), involved the expropriation of numerous PR territories to be used for military bases, military exercises and the storage of armaments (Barreto, 2002; McCaffrey, 2006). Militarization led to a surge in various sociopolitical movements for the devolution of the expropriated lands and for the halting of military practices, particularly in the case of the island municipalities of Vieques and Culebra (Baver, 2006; Berman, 2002). 
The sociopolitical and legal effects of American colonionialism have been diverse. In the legal-political sphere, PR's colonial condition may be understood in terms of a "state of exception" (Atiles-Osoria, 2012), i.e., the constitution of a space of legal indetermination where certain constitutional rights are applied, but whose citizens do not enjoy all of them. One paradigmatic example is citizenship: even though American citizenship was extended to Puerto Ricans in 1917, ${ }^{1}$ as long as they lived in PR, they were not accorded rights such as the right to vote in the election for the representatives of Congress and the president of the US. The non-recognition of these rights is based on PR's status under the Territorial Clause ${ }^{2}$ of the US Constitution, and on two central arguments developed from the so-called the Insular Cases $^{3}$ : that which establishes that "PR belongs to the US, but is not part of it," thereby setting up a relationship of ownership and/or a mercantile view of the colonial domination of PR; and, secondly, the premise that Puerto Ricans are "foreign citizens in the domestic sense." Both arguments have led to the administration of this territory through the denial of constitutional rights and guarantees, grounded in various legal loopholes (ibidem).

This legal and political indeterminacy has led to the imposition of particular political categories on this territory, and also to a high level of social conflict. The paradigmatic example was the constitution of the Comonwealth of PR or the Estado Libre Asociado de PR $(E L A)^{4}$ in 1952. This legal loophole led to the persistence of its colonial status with the consent of much of the country, the international community and, in particular, the United Nations Organization (UN). As for social conflict, this is reflected in the sociopolitical polarization between the pro-annexation and pro-status quo or pro-colonial sectors, and those that support independence.

Given PR's colonial status, there have been various actors and movements that have fought for the country's independence and self-determination. These organizations have mobilized in various ways: through struggles in the international sphere, such as via the UN and its Committee on Decolonization; through electoral mobilizations; the activation of legal

\footnotetext{
${ }^{1}$ This was possible under the Jones Law of 2 March 1917 (Jones-Shafroth Act, Pub.L. 64-368, 39 Stat. 951).

${ }^{2}$ Article IV, Section 3, Clause 2 of the US Constitution.

${ }^{3}$ The Insular Cases are a series of US Supreme Court decisions issued between 1902 and 1922, which established jurisprudence on the status of PR. They decided aspects related to the citizenship of the Puerto Rican people, the national or international character of legal-political matters in PR, and subjects relating to trade and education. In short, all involve the constitution of legal-normative referents for the positioning of the US over PR and the Puerto Ricans.

${ }^{4}$ Although the literal translation is the Associated Free State of PR, the official name is the Commonwealth of Puerto Rico.
} 
processes in local and US courts; sociopolitical mobilizations on the margin of colonial legality; and the armed struggle for independence. Although these have brought some sociopolitical and legal advances, they have not managed to put an end to American colonialism.

\section{Environmental colonialism}

The exploitation of natural resources and the extraction of wealth (in mineral, human, energy and biological terms), the destruction of the environment and related epistemologies, have traditionally been considered as primary manifestations of colonialism. This fundamental dimension, which Mattei and Nader (2008) call "plunder," is evident in different historical processes of colonization and domination used by the global North around the world. A historical survey of the various waves of colonialism shows that, despite changes in the strategies used, one of the primary goals is the plunder and exploitation of the resources of the colonized territories.

The history of colonialism shows that the exploitation of resources is grounded in a biopolitical understanding of nature. That is to say, the geopolitical nature of colonialism only becomes central as the territory yields extractable natural, human and mineral resources. Thus, the geopolitical function of colonialism is subordinated to the bios and the possibilities of enrichment from the destruction of life.

In PR, the plunder and exploitation of resources as a result of colonial-capitalist practices and environmental policies imposed by the governments of the US and PR fit perfectly into the phenomenon described above. In this sense, Concepción (1988: 128) points out that the concept of environmental colonialism

[...] refers to the exploitation of renewable natural resources: the release of toxic waste from manufacturing activities into the air, water and earth. [...] [E]nvironmental colonialism was the consequence of the technology that had been located on the island, which consumed a great deal of energy and generated high levels of contamination. The problem is that those renewable resources that have been damaged and overused are essential not only for production activities but also for all forms of life. Therefore, what is at stake is biological survival as well as economic survival. [...] This policy may be considered a new form of subordination and oppression.

Valdés (2006) extends the definition of environmental colonialism in PR to include the various processes and means through which the governments of the US and PR, together with the Puerto Rican economic elites, brought about environmental destruction as a result 
of development policies. In his historical survey, he not only highlights industrialization processes but also shows in detail how transformations in the patterns of land/coast use and agricultural production, along with militarism, urban expansion, the development of the tourist industry and gentrification directly affected the environment, leading to countless socioenvironmental mobilizations.

An important distinction should be made between the colonial practices of extraction, described by Mattei and Nader (2008), and environmental colonialism. This differentiation is due to the ideological and strategic character of environmental colonialism. While the extraction of resources imposed by colonialism is grounded in imposed and violent strategies, where the subordinate party receives nothing in exchange, environmental colonialism functions as an ideological system of exploitation that is planned and operates with the consent and participation of the national elites. The extraction, contamination and destruction of the environment is legitimized through the promise of a reward; that is to say, a system of management of natural and mineral resources is implemented for which the economic elites of the country receive something in exchange (e.g., development, modernization, etc.). Thus, environmental colonialism is no longer limited to the exercise of biopower over the colonial territory, but includes a sociopolitical and legal structure which enables the exploitation of resources with the consent of the parties concerned.

This legal-political structure of environmental colonialism finds a new support in neoliberalism. Neoliberalism interprets natural resources as "consumer products" included in the market economy (Nixon, 2011). Smith (2009: 5-6) points out that:

[...] intensified commodification, marketization and financialization of nature is of course an integral element of a much larger project of neoliberalism. Neoliberalism's substitution of private market economic measurement for social calculation, and its insistence that anything of social worth must be tradable in the global market, applies precisely to the emergence of new markets in ecological commodities, mitigation banking and environmental derivatives.

Thus, we find ourselves before a new version of the so-called "social function" of nature. This is also a new neoliberal geography, where "natural resources" have become "ecological commodities" (Bakker, 2010). With this development of neoliberalism, environmental colonialism is reinforced and new strategies for control and domination arise, such as biopiracy, the mass purchase of agricultural lands, carbon (CO2) emissions trading, and other contemporary enrichment practices based on the commodification and consumption of nature (Nixon, 2011). 
Given this biopolitical and neoliberal dimension of environmental colonialism, it is not surprising that anticolonial movements have been very involved in the struggle for environmental justice in PR. The extensive tradition of anticolonial struggle has shown that liberation in the biopolitical domain is just as important as liberation in the geopolitical domain. Thus, it is only natural that the desire for emancipation should transcend the geopolitical and become biopolitical and/or involve investment in physical, environmental, epistemological, cultural and moral emancipation.

\section{From criminalization to eco-terrorism}

Processes of repression of social mobilizations may be designed according to two paradigms: on the one hand, there is the use of political violence to detain, intimidate and demobilize organizations that challenge the state's legitimacy; and on the other, the use of law and legal discourses as a mechanism to delegitimize those organizations.

For the purposes of this article, the former will be defined under the concept of repression. This mechanism implies the use of violence by the state and para-state organizations for extralegal activities such as: abductions, political assassinations and 'disappearances'; attacks with explosives on the property of militants and their organizations; and the militarization of the public space and disproportionate use of police force. I also include in the term 'repression' the use of mechanisms of surveillance, persecution and coercion that are on the margins of the law, and whose legality may be questioned. In the case of PR, we are referring to the practice of "carpeteo," ${ }^{5}$ the infiltration of sociopolitical movements by state agents, recordings, photographing and other manifestations of symbolic violence.

As for criminalization mechanisms, these refer to the use of the law to coopt and delegitimize sociopolitical organizations. They include: drawing up special laws; ${ }^{6}$ using the courts and state law to solve situations of a political nature; imposing specific imprisonment policies for political actors; and outlawing organizations, either in terms of positive law or

\footnotetext{
5 "Las Carpetas" or "el carpeteo" was a surveillance programme carried out by the Intelligence Division of the PR Police between the 1930s and 1990. It involved primarily the continuous surveillance of members of independence organizations, socialist groups and other social organizations. This operation was in keeping with the COINTELPRO [Counter Intelligence Program] established by the FBI (Bosques Pérez and Colón Morera, 1997).

${ }^{6}$ For example, the gagging law, the Sedition Act and the criminal categories pertaining to enemy criminal law (Atiles-Osoria, 2012).
} 
through legalized discourse. The latter refers to the use of official or government discourse to establish that a particular organization is criminal, subversive and/or terrorist, even when this has not been proved by a legal or political body - in other words, it involves the use of delegitimation campaigns to create a common understanding of the antagonistic agent.

This last point is presented by Concepción (1995) in her analysis of the repression of the anti-mining struggles in the 1970s. She claims that two strategies were applied in the process: firstly, they tried to gather support for the project arguing that technologies to control contamination existed and were available; secondly, they sought to destabilize the opposition (Concepción, 1995: 119). As regards the intention to destabilize the opposition, she argues that

[...] the government tried to discredit the opposition and by doing so to divert attention from the issues. Government officials and leading senators focused on the political beliefs of opponents and called them subversives, while downplaying their concerns as primarily politically motivated. An editorial of the newspaper El Mundo explained the opposition by proindependence interests and organizations as 'narrow nationalism of those who do not want US companies on the island, rather than fair reasons'. (Ibidem: 120)

As can be seen, there was as much persecution and repression of the environmental movements as of the anticolonial movements. Likewise, the repressive measures described by Concepción (1995) became the norm in multiple environmental conflicts in PR. These practices also involved surveillance and the 'carpeteo' of environmental activists, as well as arrests and incarceration (Paralitici, 2011). One case where the use of repressive and criminalizing practices was particularly flagrant was in the struggles against the American naval bases at Culebra and Vieques (before 1999). With the effects of contamination, and the insecurity and environmental damage caused by over 30 years of military training exercises, the 1970s represented the high point in the struggle to get rid of the naval base on the island of Culebra. In these mobilizations, antiocolonial movements, including the Puerto Rico Independence Party (PIP) and the Puerto Rico Socialist Party (PSP), played a central role. As a result of these struggles, in 1975, the naval base stopped its military exercises in Culebra and passed to the neighbouring island of Vieques.

In the context of the protests against the naval base at Culebra, the PIP used a tactic that was new in PR, and which involved the fishermen and members of the community. This consisted of incursions into the areas of the naval base reserved for exercises and manoeuvres, and involved civil disobedience and/or peaceful disobedience. This led to the 
arrest of several members of different organizations, most of whom were sentenced to between three and six months in prison by the US Federal Court in PR. ${ }^{7}$ The struggle against the presence of the US Navy in Vieques also led, on 11 November 1979, to the political assassination of the anticolonial and environmental activist Ángel Rodríguez Cristóbal in a prison at Tallahassee, while he was serving a six-month sentence for acts of civil disobedience (Paralitici, 2011). This killing is an example of how the repressive tactics and strategies deployed against the anticolonial movements were also used against the socioenvironmental movements between 1960 and 1990.

Following the events of $9 / 11$ in the US, the mechanisms of repression intensified with the enactment of the Patriot Act. This law, designed to deal with "terrorist threats," incorporated a new element in the definition of terrorism, namely the concept of ecoterrorism, which was included in the Patriot Act as a way of criminalizing "ecotage" and/or economic sabotage - i.e., a form of resistance that involves action against inanimate objects (Vanderheiden, 2005). This type of action, traditionally used by environmentalist movements that advocate direct action, became popular in the 1980s, but after 9/11 became considered as acts of terrorism by the US. This transformation of ecotage into ecoterrorism has given governments and economic interests carte blanche to act directly against environmentalist movements in the US, including when their actions fall within the bounds of civil disobedience and/or ought not be construed as terrorist acts.

In the context of the socioenvironmental struggles in PR, ecotage has scarcely been used. ${ }^{8}$ Instead, peaceful civil disobedience has been the most widespread tactic used by Puerto Rican socioenvironmental movements. Hence, the government has opted to consider civil disobedience as ecoterrorism. That is to say, in PR, it is the "occupation of building sites" that has been considered as ecoterrorism.

\section{Socioenvironmental struggles}

According to Valdés (2006), there are four types of socioenvironmental organizations in PR: 1) conservationists, environmental NGOs and organizations made up predominantly of

\footnotetext{
${ }^{7}$ This was the case of Rubén Berrios Martínez and the leaders of the PIP, who were arrested on 21 January 1971 on the beaches of Culebra and sentenced to three months' imprisonment (Paralitici, 2011).

${ }^{8}$ In my research I have identified only one occasion when this kind of action was carried out during the 1990s. The case involved the sabotage of tubes and machinery destined for the construction of the North Coast superaqueduct by the Boricua Popular Army (also known as Los Macheteros), on 31 March 1998.
} 
academics and other intellectuals; 2) sociopolitical-environmental NGOs, formed of environmental, religious, political, social and worker groups; 3) environmental groups fighting against a specific phenomenon that affects some aspect of the environment (these groups are generally formed from strategic coalitions of social, political, religious, environmental and conservationist groups); 4) community environmental organizations, usually composed of grassroots groups that mobilize to protect their own communities. Although these organizations are composed of specific sectors of society, they display a certain level of diversity, depending on the demographic features of their communities (Valdés, 2006: 45). The activities and struggles of these environmental organizations have unfolded over two broad periods: the first, between the 1960s and 1990s, and the second between 1999 and 2012. This division is based on the configuration of the environmental movements and on the mechanisms of repression and criminalization employed by the governments of the US and PR.

In broad terms, the first environmental struggles in PR were marked by the presence of Puerto Rican anticolonial movements. Organizations such as the Pro-Independence Movement (MPI), the PSP, PIP and the Pro-Independence University Federation (FUPI), played a central role in the support and organization of environmental struggles between 1960 and 1990. These struggles can be viewed in terms of two major goals: there were those that opposed projects designed by the governments of PR and the US, and others that demanded access to and democratization of the use and management of resources. With regard to the former, examples of struggles against US-proposed projects are the movements for the preservation of the Lajas agricultural valley in the 1990s (González Cruz, 2008) and the struggles to oust the US Navy from the islands of Vieques and Culebra (from 1960 to 2003). Movements opposing PR-government projects include the anti-mining struggles (between 1960 and 1995), mobilizations against the construction of the North Coast super-aqueduct ${ }^{9}$ in the 1990s (ibidem), and the struggles for the development of stricter environmental policies.

As regards the second group of mobilizations, these include the struggles against "urban development" projects proposed by the colonial elites, such as: movements opposing the privatization of beaches, better known as "Las Playas pal' Pueblo" (1960 to 2012);

\footnotetext{
${ }^{9}$ A water distribution system that runs from the north of the Island and supplies water to San Juan (capital of PR) and its metropolitan area.
} 
movements for the conservation and preservation of woods and wetlands; movements for the decontamination of zones affected by industrial and military activities; and movements against urban speculation and gentrification (Baver, 2012). In these cases, we find that most of the mobilizations have been carried out by community organizations that receive the support of sociopolitical and anticolonial groups. It is probably in these mobilizations that we find the greatest use of the law by socioenvironmental movements as well as by the socalled "developmentalists," or investors. It is interesting to note that in these antagonistic spaces, the law and legal discourses become a sphere for both the resistance to and the advancement of economic interests.

From the 1990s, the socioenvironmental mobilizations underwent a process of transformation. In this context, the environmental movements took the form of social mobilizations that broadly influenced Puerto Rican sociopolitical struggles. As we have seen in the typology presented by Valdés (2006), one of the most important features of Puerto Rican socioenvironmental movements is their capacity to combine and mobilize various social, political, legal and community sectors. This capacity for action was exemplified most intensely from the second wave of protests against the naval base at Vieques (1999-2003), in which anticolonial movements, civil society and socioenvironmental movements played a central role (Barreto, 2002; McCaffrey, 2002).

\section{"Peace for Vieques"}

On 19 April 1999, the US Navy was carrying out military manoeuvres in Vieques when a bomb launched from one of its aeroplanes fell onto a security post on a bombing range. In that security post were several civil employees of the naval base including David Sanes Rodríguez, who died as a result of the impact. His death was the spark that ignited the second wave of mobilizations against the naval base at Vieques.

These protests, which ran between April 1999 and May 2003, were symbolically one of the most important sociopolitical periods for Puerto Ricans. This is not only because the navy base left Vieques, but also because various levels of action came together, with solidarity between different sociopolitical sectors of the country and the international sphere. This convergence was due to what we call "civil society," which in PR, unlike other cases, refers to the joint action of anticolonial, socialist and environmental movements, 
religious groups, traditional political parties, social organizations and communities (Colón \& Rivera, 2006).

This new struggle against the naval base of Vieques symbolized the end of a strategic and ideological transition that had begun in 1990 with the mobilizations for the protection of the Valle de Lajas and against the naval base in Vieques (González, 2008). The new mobilizations consisted of acts of civil disobedience carried out on the lands that were used for military manoeuvres (as already mentioned, this tactic was used in the first period of mobilizations). Thus, in the name of the human rights of the Vieques people, against environmental contamination and for the devolution of the lands that belonged to the Puerto Ricans, thousands of people joined together to put an end to the military manoeuvres. Under the slogan "Peace for Vieques, US navy out of Vieques and All PR with Vieques," on 21 February 2000, more than 100,000 people marched through the streets of San Juan demanding the immediate removal of the naval base (Paralitici, 2011).

In the face of these protests, which were attracting growing support from the citizens and the international community, ${ }^{10}$ the naval base and US government began a campaign of repression against the demonstrators. On 4 May 2000, a contingent of federal agents began breaking up the civil disobedience encampments that had been set up in the area of the bombing range at Vieques and arresting protestors. Between 2000 and 2003, two thousand people were arrested for civil disobedience. All were tried in the US Federal Court in PR, and given prison sentences that extended from a few hours to various years. It is interesting to note that although civil disobedience is considered a minor offence in the US, usually punished with a fine or a warning, the colonial status of PR permits this type of excess (Susler, 2002). Furthermore, many of the protestors that were arrested denounced abuse and violation of their human and civil rights (Reverón, 2002).

Finally, when the US Navy withdrew from Vieques on the $1^{\text {st }}$ of May 2003, certain events took place that acquired importance. Firstly, during the celebrations that followed this victory, a group of activitists destroyed vehicles and a guard-house, resulting in the arrest of the demonstrators and the beginning of a criminalization campaign that involved both the law and the media; in the end, they were given sentences of three to six years in federal prison (Paralitici, 2011). Secondly, it led to the start of what Baver (2006) has called a new

\footnotetext{
${ }^{10}$ It should be pointed out that the UN Decolonization Committee was in favour of the immediate removal of the Vieques naval base in 2000.
} 
stage in the Vieques struggle, which has involved mobilizations for the cleaning, decontamination and devolution of the lands occupied by the naval base. This is a significant stage, since the lands were transferred to the US Fish and Wildlife Service and the Conservation Trust without being decontaminated. Berman (2010) points out that the future development of the island of Vieques depends largely upon the cleaning and decontamination of the areas affected by more than 40 years of military practices. This political-economic demand for environmental justice indicates the new scope of the struggle and the new connections of resistance to environmental colonialism.

\section{From Vieques to Paseo Caribe}

With the positive results achieved by the presence of civil society in the struggles against the naval base of Vieques, after 2003 the mobilizations for environmental justice took on similar organizational models, i.e., the activation of diverse sectors across a broad front. Thus, in the first decade of the new millennium, there were various socioenvironmental mobilizations that opposed both environmental colonialism and the development policies implemented by the government of PR and the economic elites. ${ }^{11}$ These included the movements opposing the construction of the Paseo Caribe housing complex in 2007.

This project, proposed by the national economic elites and the transnational hotel company Hilton, involved the construction of a residential building in the coastal area of Condado in San Juan, which endangered the San Jerónimo Fort, one of the most important historical structures of the region. It also aimed to privatize access to this historic monument and the beaches. The opposition to this project was conducted through civil disobedience, popular demonstrations and the incorporation of a legalized discourse of possible alternatives to the project. The best example of this legalistic discourse was the creation of a People's Court (on 16 November 2007) in which possible violations incurred by the developers were evaluated, producing a "final decision" in which it was established that "the

\footnotetext{
${ }^{11}$ The mobilizations included: struggles for the preservation of the forests and areas of great biodiversity (e.g., the San Patricio Meadows, the Northeast Ecological Corridor, the Caño Tiburones and Caño Martin Peña nature reserves); protests for the protection of coastal areas; struggles for the cleaning and rehabilitation of the areas affected by military and industrial activities; and community mobilizations against the construction of radio and telephone aerials, amongst other things.
} 
project violated the laws of public environmental policy and zoning, amongst other violations." 12

Although there was no significant campaign of repression and criminalization as a result of these mobilizations, the opposition to this project and the occupation of building sites by environmental groups served as a pretext for the presentation in 2009 of a new law designed specifically to criminalize socioenvironmental mobilizations.

\section{The state of emergency on energy and new patterns of criminalization}

From 2009, the government of PR developed a new public policy that directly affected the environment, resulting in the emergence of new socioenvironmental protests and the criminalization of these movements. More specifically, the new public policies on the environment have brought two major legal-political effects: the declaration of a state of energy emergency and the adoption of specific laws criminalizing socioenvironmental protest.

With the commencement of the neoliberal administration of Luis Fortuño (PNP), the thesis was put forward that PR lived in a "state of energy emergency." ${ }^{13}$ The declaration of this state of emergency was made under Executive Order OE2010-034, which established that, as $70 \%$ of electrical energy production in PR was derived from petroleum-based fossil fuels, which brought high levels of contamination and high production costs, it was necessary to seek cheaper environmentally-friendly alternatives, preferably of a renewable nature. Thus, the Energy Affairs Administration $(A A E)^{14}$ was set up, and a programme was developed to seek out alternatives to the current situation.

Up to this point, one can agree with the assumptions of "energy emergency" and with the socioenvironmental and economic problems caused by oil dependence, and therefore with the need to find alternative sources of energy. However, the declaration of a state of emergency has various sociopolitical and legal implications that should not be overlooked. For one, it means that decisions regarding the country's future on energy, environmental, sociopolitical and economic matters can be made unilaterally without prior consultation of

\footnotetext{
${ }^{12}$ See the final decision at http://myweb.ecomplanet.com/eldt6383/mycustompage0436.htm.

${ }^{13}$ The declaration of the state of energy emergency was in keeping with the state of fiscal emergency declared in 2009. Both declarations revealed the present administration's support for an authoritarian model of government, which does not abide by standards of democratic governance.

${ }^{14}$ For details on this new agency, see http://www.aae.gobierno.pr/ (accessed on 5 August 2013).
} 
the citizens. It also renders invisible the possible effects of projects that directly affect the community. This element of exceptionalism ${ }^{15}$ demarcates a new sphere of legal-political action under the state of emergency/exception, since this has traditionally been reserved for contexts where the rule of law is threatened by social revolt, revolution or war (Agamben, 2005). Hence, what is new in this case is that the state of emergency is applied to a problem that does not directly threaten the colonial administrative structure.

As a result of the declaration of a state of energy emergency, the Fortuño administration proposed various projects of great environmental impact, including: 1) the conversion of oilbased electrical plants to natural gas; 2 ) the creation of a pipeline to transport natural gas $155 \mathrm{kms}$ from the south to the north of the island, bringing impacts for the environment, the groundwater, archaeology and residential areas; 3 ) the construction of waste incineration plants in the north of the country; and 4) the installation of wind turbines in areas of high agricultural production.

All these proposals provoked a series of important socioenvironmental protests. One of the most significant was the opposition to the construction of the northern gas pipeline. These mobilizations are an example of the way socioenvironmental struggles have brought together various different actors and proposals. In this case, the actors included the Casa Pueblo organization, community organizations, anticolonial movements and civil society.

The specific law that criminalizes socioenvironmental protests is Law No. 158, of 29 October 2010, ${ }^{16}$ which states that it serves "the purpose of establishing the obstruction and paralysation of building works as a new felony." ${ }^{17}$ The criminalization of socioenvironmental protest is laid out in the following lines of this law:

Anyone who intends to temporarily or permanently obstruct any building work, whether public or private, or land work that have the permission, authorization or endorsement of the agencies concerned [...], will incur a felony of the fourth degree.

\footnotetext{
${ }^{15}$ This was established by Law No. 32 of 14 March 2011, which amended Article 12 of Law no. 76 of 5 May 2000.

${ }^{16}$ Law No. 3, of 4 February 2011, added a new article (246-A) to Law No. 149 of 18 June 2004, amended, known as the "Puerto Rico Penal Code," with the purpose of categorizing as a felony the obstruction of public services in educational and health institutions and other buildings that provide governmental services to the public. See http://www.lexjuris.com/lexlex/Leyes2011/lexl2011003.htm (accessed on 5 August 2013).

${ }^{17}$ See the webpage: http://www.lexjuris.com/lexlex/Leyes2010/lexl2010158.htm (accessed on 5 August 2013). This amendment to the Penal Code is known popularly as the "Tito Kayak Law," since it was seen as a reaction to the protests of the well-known Puerto Rican activist and environmentalist Alberto de Jesús "Tito Kayak."
} 
By classifying the occupation of a public or private work as a serious felony, the type of protest that is most effective in the struggles for environmental justice (civil disobedience) is criminalized. However, the legislator legitimizes this criminalization measure through a public safety argument. This is made clear in the preamble to the law, which argues that the state's interest is to "protect the life and property of its citizens" by preventing them from entering buildings or facilities that are under construction, given the risk of serious injury for anyone that is not properly trained. Obviously it is nowhere stated that the aim is to prohibit protests against projects that openly violate environmental legislation; however, this is clear from the classification of the following activities as felonies:

(a) Preventing the entrance or access of employees, vehicles and people, including suppliers of materials, authorized by the owner, contractor or site manager; (b) Occupying lands, machinery or spaces that form part of the building site or the land movement site; (c) The court will also impose a sentence for restitution.

I believe that, by classifying civil disobedience and socioenvironmental protest as a serious offence, the administration aims to put an end to the contingent practices developed by Puerto Rican environmental movements. This tactical and strategic rupture will have the same implications as the classification of ecosabotage as ecoterrorism under the Patriot Act. That is to say, this law delegitimizes all environmental protest actions, and makes it impossible to take action without running the risk of being accused of a serious felony; it also implies that Puerto Rican socioenvironmental movements have achieved such a degree of recognition that the PR government has decided to demobilize them through the constitution of criminalization mechanisms specific for the purpose.

The first people to be accused under the new law were a group of six protestors belonging from the Frente Rescate Agrícola (FRA, "Agricultural Rescue Front"). They were arrested on 15 December 2011 while carrying out acts of civil disobedience on the agricultural lands of the southern town of Santa Isabel, that is, while "they were demonstrating in a public entrance to the farmlands where the company Pattern Energy planned to install sixty-five 131-metre high wind turbines, disturbing at least 1455 hectares of the Santa Isabel agricultural valley." ${ }^{18}$ At present, the accused are facing a minimum of six months in prison.

\footnotetext{
${ }^{18}$ Quoted from "No culminan los procesos legales contra los seis manifestantes arrestados en Santa Isabel," by the Frente Rescate Agrícola (FRA), 03.02.2012. Available at http://pr.indymedia.org/news/2012/02/50901.php (accessed on 5 August 2013).
} 
This movement to oppose the installation of wind turbines is a fundamental part of the struggles that are currently taking place against the neoliberal policies and state of energy emergency declared by the Fortuño administration. There have been demonstrations against the northern gas pipeline and the incinerator in the northern town of Barceloneta, and others calling for the protection of the northwest ecological corridor - just some of the protests that could be affected by this new criminalization measure. For the moment, we know that projects such as the pipeline have been strongly questioned by the town and by all the administrative bodies that have to authorize it.

\section{Conclusions}

This article has attempted to sketch the conflictual situation between socioenvironmental movements, environmental colonialism and the criminalization of socioenvironmental protest. In general terms, it has shown that the struggles for the preservation of the environment are an essential part of anticolonial struggles, while also describing the development of the Puerto Rican socioenvironmental movements from the moment of their formation until they became a central force in the social and political life of the country. Their broad trajectory not only provides evidence of a tradition of struggle and the central role played by environmental justice in the Puerto Rican sociopolitical imaginary, but also shows the capacity to resist repression and environmental colonialism.

For its part, environmental colonialism continues to be a key factor for identifying contingent positionings and strategies. As I have shown, the governments of the US and PR have conceived mechanisms of repression and criminalization as a response to every demand made by the Puerto Rican movements. Hence, in the first period of socioenvironmental struggle, the governments implemented the same mechanisms of repression that had been designed and applied against the anticolonial movements. Later, in the context of the struggles against the Vieques naval base, they put greater emphasis upon repressing civil disobedience. Finally, in the post 9/11 era, acts of sabotage were classified as ecoterrorism, in the case of the US, and civil disobedience and the occupation of buildings and projects that affect the environment were classified as serious felonies in the case of PR.

These reconfigurations of the mechanisms of repression and criminalization raise a challenge for the socioenvironmental movements, a challenge that may be expressed through the following question: how to activate processes of socioenvironmental struggle in 
the post- 9/11 era? In the same way, the environmental colonialism imposed by the US with the consensus of the government of PR presents an additional challenge: how to emancipate oneself from all forms of power, not merely geopolitical, but also biopolitical? I consider that civil society, the anticolonial and socioenvironmental movements have demonstrated their ability to advance a new sociopolitical, environmental and economic agenda irrespective of the forms of power imposed on the country. All that is missing is that they be permitted to go forward. Thus, while there is repression, criminalization and colonialism, there will be movements, actors and subjectivities that raise their voice against colonialism and on behalf of environmental justice.

Translated by Karen Bennett

Revised by the author and Teresa Tavares

\section{References}

Agamben, Giorgio (2005), State of Exception: Homo Sacer II, 1. Chicago: University of Chicago Press.

Atiles-Osoria, José M. (2012), "The Criminalisation of Anti-Colonial Struggle in Puerto Rico," in Scott Poynting \& David Whyte (eds.), Counter-Terrorism and State Political Violence. London: Routledge, 156-177.

Bakker, Karen (2010), "The Limits of 'Neoliberal Natures': Debating Green Neoliberalism," Progress in Human Geography, 34(6): 715-735.

Barreto, Amílcar A. (2002), Vieques, the Navy, and Puerto Rican Politics. Gainesville: University of Florida Press.

Baver, Sherrie L. (1993), The Political Economy of Colonialism: The State and Industrialization in Puerto Rico. Westport: Praeger.

Baver, Sherrie L. (2006), "'Peace Is More than the End of Bombing': The Second Stage of the Vieques Struggle," Latin American Perspectives, 33(1): 102-115.

Baver, Sherrie (2012), "Environmental Struggles in Paradise: Puerto Rican Cases, Caribbean Lessons," Caribbean Studies, 40(1): 15-35.

Berman Santana, Deborah (1996), Kicking Off the Bootstraps: Environment, Development, and Community Power in Puerto Rico. Tucson: University of Arizona Press.

Berman Santana, Deborah (2002), "Resisting Toxic Militarism: Vieques versus the U.S. Navy," Social Justice, 29, 2(1-2): 37-47.

Berman Santana, Deborah (2010), "Struggles for Ex-Base Lands in Puerto Rico," Peace Review: A Journal of Social Justice, 22: 158-163.

Bosques Pérez, Ramón; Colón Morera, José (eds.) (1997), Las carpetas: derechos civiles y persecución política en Puerto Rico. Río Piedras: CIPDC.

Colón Morera, José; Rivera Santana, José (2006), "New Dimension in Civil Society Mobilization: The Struggle for Peace in Vieques", in Ramón Bosque Pérez \& José Colón Morera (eds.), Puerto Rico under Colonial Rule: Political Persecution and the Quest for Human Rights. Albany: State University of New York Press, 207-232. 
Concepción, Carmen M. (1988), "El conflicto ambiental y su potencial hacia un desarrollo alternativo: el caso de Puerto Rico," Ambiente y Desarrollo, IV(1-2): 125-135.

Concepción, Carmen M. (1995), "The Origins of Modern Environmental Activism in Puerto Rico in the 1960s," International Journal of Urban and Regional Research, 19(1): 112-128.

Dietz, James L. (1989), Historia económica de Puerto Rico. Rio Piedras: Ediciones Huracán.

García Muñiz, Humberto; Vega Rodríguez, Gloria (2002), La ayuda militar como negocio: Estados Unidos y el Caribe. San Juan: Ediciones Callejón.

González Cruz, Michael (2008), "Puerto Rican Revolutionary Nationalism: Filiberto Ojeda Ríos and the Macheteros," Latin American Perspectives, 35: 151-165.

Mattei, Ugo; Nader, Laura (2008), Plunder: When the Rule of Law is Illegal. London: Blackwell.

McCaffrey, Katherine T. (2002), Military Power and Popular Protest: The U.S. Navy in Vieques, Puerto Rico. New Brunswick/London: Rutgers University Press.

McCaffrey, Katherine T. (2006), "Social Struggle against the U.S. Navy in Vieques, Puerto Rico: Two Movements in History," Latin American Perspectives, 33(1): 83-101.

Nixon, Rob (2011), Slow Violence and the Environmentalism of the Poor. Cambridge/London: Harvard University Press.

Paralitici, José "Che" (2011), La represión contra el independentismo puertorriqueño: 1960-2010. Cayey: Publicaciones Gaviota.

Reverón Collazo, Wilma (2002), "La violación de los derechos humanos de los desobedientes civiles en Vieques", in Luis Nieves Falcón (org.), Violation of Human Rights in Puerto Rico by the United States. San Juan: Ediciones Puerto, 175-181.

Smith, Neil (2009), "Nature as Accumulation Strategy," Neil Smith webpage. Accessed on 16.10.2012, at http://neil-smith.net/wp-content/uploads/2009/10/nature-as-accumulation-strategy.pdf.

Susler, Jan (2002), "Comparison of Civil Disobedience Sentences," in Luis Nieves Falcón (ed.), Violation of Human Rights in Puerto Rico by the United States. San Juan: Ediciones Puerto, 193199.

Valdés Pizzini, Manuel (2006), "Historical Contentions and Future Trends in the Coastal Zones," in Sherrie L. Baver; Barbara Deutsch Lynch (eds.), Beyond Sun and Sand: Caribbean Environmentalisms. New Brunswick: Rutgers University Press, 44-64.

Vanderheiden, Steve (2005), "Eco-terrorism or Justified Resistance? Radical Environmentalism and the 'War on Terror'," Politics \& Society, 33(3): 425-447. 